\title{
The Tli Kwi Cho (DO27 and DO18) Diamondiferous Kimberlite Complex Slave Craton, Northwest Territories, Canada
}

\author{
Doyle, B.J. ${ }^{1}$, Kivi, K. ${ }^{1}$, Scott Smith, B.H. ${ }^{2}$ \\ 1. Kennecott Canada Exploration Inc., Suite 354, 200 Granville St, Vancouver, V6C 1S4, BC. Canada \\ 2. Scott-Smith Petrology Inc. 25-55 Edgemont Boulevard., Nth. Vancouver, V7R 2M9, BC. Canada
}

The Tli Kwi Cho diamondiferous kimberlite complex is a member of the Lac de Gras cluster of kimberlites located $360 \mathrm{~km}$ north of Yellowknife at lat. $64^{\circ} 19^{\prime} \mathrm{N}$, long. $109^{\circ} 48^{\prime} \mathrm{W}$, in the Northwest Territories of Canada. The kimberlites are held under mineral claims belonging to the DHK joint venture whose ownership consists of 40\% Kennecott Canada Exploration Inc. (KCEI), 10\% SouthernEra Resources Inc, 15\% Aber Resources Ltd. and DHK 35\% (Dentonia Resources Ltd., Horseshoe Gold Mining Inc. and Kettle River Resources Ltd.).

The kimberlite complex is obscured by $20 \mathrm{~m}$ to $55 \mathrm{~m}$ of till and up to $10 \mathrm{~m}$ of lake water. Tli Kwi Cho was discovered when two distinct magnetic and electromagnetic anomalies, designated DO27 and DO18, were drill tested in 1993. DO18 occurs to the north of DO27. The kimberlite was intruded into medium grained two-mica granite of the Archean Contwoyto terrain. This terrain occupies the SE side of the Slave Craton. The granite is probably syndeformational and was emplaced around 2.62 to $2.59 \mathrm{Ga}$ (Hoffman 1989).

The kimberlite complex consists of a precursor hypabyssal sill and dyke intrusive event followed by up to four pyroclastic/volcaniclastic kimberlite events. Four main textural rock types with distinct megascopic characteristics dominate different areas of Tli Kwi Cho.

These comprise:

i. HK - DO27 hypabyssal macrocrystic monticellite kimberlite +/- minor kimberlite breccias, central dyke/sill complex.

ii. PK - main southern DO27 green crater-facies kimberlite or lapilli-bearing olivine tuff.

iii. VK - northern DO27 black crater-facies kimberlite or shale-rich olivine lapilli tuff.

iv. XPK - DO18 xenolith- and xenocryst-rich lapilli-bearing olivine tuff +/-breccias/microbreccias.

The presence of sediments and wood in the tuffaceous kimberlites show that, at the time of kimberlite emplacement, there was sedimentary cover over Archean basement which has subsequently been eroded. Variation in the nature of the shale clasts and the presence of mudstone, sandstone and wood suggests that different stratigraphic units must have been present. The Tli Kwi Cho kimberlite complex has proven very difficult to date due to the lack of suitable dateable minerals. The most reliable method, palynolgy, has given a maximum age of $74 \mathrm{Ma}$. The similarity of the terrestrial flora (wood fragments) in pyroclastic and volcaniclastic rocks with other reliably dated kimberlites suggests that an Eocene age is likely.

The four main phases of kimberlite in the Tli Kwi Cho kimberlite complex have contrasting mantlederived xenocrysts. The size and abundance of the olivine macrocrysts vary in each of the rock types. The HK unit contains fresh olivine up to $20 \mathrm{~mm}$ in size while the olivines in PK are fresh or partly altered and mainly $<5 \mathrm{~mm}$. In VK the olivines are mainly $<2-3 \mathrm{~mm}$ (up to $5 \mathrm{~mm}$ ) and in XPK the altered olivines are $<2-3 \mathrm{~mm}$ (up to $7 \mathrm{~mm}$ ). The PK unit contains the most garnet, diopside and 
ilmenite. The XPK kimberlite contains the next most abundant xenocrysts, then VK, with HK containing the least. The diamond contents of the rock types is also different and distributed in the same manner as the xenocrysts with PK containing the most and HK the least. Unlike the other rock types, the garnets in HK can have $300 \mu \mathrm{m}$ thick kelyphite coronas and the diopsides are rounded oviods rather than square laths. Limited whole-rock analysis (six samples) of matrix material from the four rock types suggest that $\mathrm{HK}$ has higher $\mathrm{Ba}, \mathrm{Sr}, \mathrm{Ca}$ and lower $\mathrm{S}$ than the other rock types.

The distinctive nature of these four rock types suggests that they result from different phases and styles of kimberlite emplacement. Firstly HK is hypabyssal while the other three rock types are extrusively formed volcaniclastic kimberlites. Among the volcaniclastic rocks, for example, the juvenile lapilli in VK contain totally altered olivine, more vesicles as well as less common and finer grained spinel than those in PK. This strongly suggests that the lapilli formed in different pyroclastic events. Other differences include the microscopic nature of the shale clasts and the alteration style of the olivine. Furthermore, the different types of inter-clast matrices suggest different modes of deposition. In PK the inter-clast matrix is composed of clearer serpentine $+/-$ carbonate and lacked fines while in the VK the matrix contains common fines. The PK is interpreted as being primary sub-aerial pyroclastic kimberlite while the VK clearly was deposited in different conditions, perhaps by resedimentation. The thorough mixing of granitic material in XPK shows another style of eruption and/or deposition.

The hypabyssal nature of the kimberlite, the absence of shale xenoliths and the distribution of this rock type show that the HK is an intrusive hypabyssal sheet/dyke complex which invaded in-situ granite within the central part of Tli Kwi Cho. The 3D distribution of this rock type shows broad sub-horizontal zones of granite and hypabyssal kimberlite suggesting that the HK forms an overall sill-like complex of sheets possibly similar to that at Mayeng in South Africa (Apter et al. 1984). Sheets greater than $1-2 \mathrm{~m}$ thick are unusual among reported kimberlites. According to Mitchell (1986), sills can range up to $10 \mathrm{~m}$ thick in granitic country rocks and rarely up to $45 \mathrm{~m}$.

The HK event preceded PK and VK and probably XPK. The xenolith-poor PK, the shale-rich VK and the xenolith rich XPK are distinctly different types of volcaniclastic kimberlite that formed by at least three separate eruptions at different volcanic centres forming separate craters. The PK and VK craters were excavated into areas of granite which had already been intruded by HK. PK forms a bowl shape crater at least $250 \mathrm{~m}$ deep with an area of 9 ha tapering to $1-2 \mathrm{~m}$ deep on the rims of the bowl. XPK forms a pipe like body at least $250 \mathrm{~m}$ deep and 6 ha in area. Drilling has not defined the shape and form of VK though it is at least $50 \mathrm{~m}$ deep and 1 ha in area. There is no evidence to suggest the sequence in which the three separate craters formed. The sediments overlying the granitic basement would have formed the upper crater wall material in all the volcanic centres. At least some of this material was poorly consolidated at the time of kimberlite emplacement and the craters would therefore probably flare outwards. The flaring of the PK unit may suggest that the granite/sediment unconformity may not have occured too far above the present day surface.

The classic kimberlite emplacement model includes the formation of diatreme-facies rocks (sensu Hawthorne 1975; Clement and Skinner 1985) infilling a steep sided pipe below the crater. There is no evidence to suggest that any of the observed rocks in Tli Kwi Cho include, or were associated with or derived from, diatreme facies material.

The multiple rock types and their unusual configuration added complexity to exploring and delineating Tli Kwi Cho. The DO27 magnetic anomaly was the main reason for selecting Tli Kwi 
Cho for exploration, yet this anomaly was not explained until HK was drilled in the $22^{\text {nd }}$ drill hole. The centre of PK was not found until the fifth drill hole.

The Tli Kwi Cho kimberlite complex was tested for economic concentrations of diamonds. In 1994 a 1257.7 tonne sample was collected by underground decline $90 \mathrm{~m}$ below surface from one of the HK sills. This sample returned a grade of $0.013 \mathrm{ct} / \mathrm{t}$. Previously this rock type has been referred to as diatreme in corporate news releases, it is now termed HK. The decline was also developed into the PK rock type from which a 3003.3 tonne sample was extracted. This sample returned a grade of $0.36 \mathrm{ct} / \mathrm{t}$. Diamonds from the PK were priced at \$US 21.70/ct at 1994 prices. The XPK (DO18) was tested in 1996 using a large diameter $(15 \mathrm{~cm})$ drill core. A 6.88 tonne sample was extracted and returned a grade of $0.09 \mathrm{ct} / \mathrm{t}$. At these grades and prices the Tli Kwi Cho kimberlite complex is considered sub-economic.

\section{References}

Apter, D.B., Harper, F.J., Wyatt, B.A. and Scott Smith, B.H., 1984. The geology of the Mayeng sill complex, South Africa. Proceedings of the Third International Kimberlite Conference. Editor J. Kornprobst. Developments in Petrology 11A, Vol 1., p. 44-57.

Clement, C.R., 1982. A comparative geological study of some major kimberlite pipes in the northern Cape and Orange Free State. Unpublished Ph.D. thesis, University of Cape Town, South Africa.

Clement, C.R., and Skinner, E.M.W., 1985. A textural-genetic classification of kimberlites. Transactions of Geological Society of South Africa, 88, p. 403-409.

Hawthorne, J.B., 1975. Model of a kimberlite pipe. Physics and Chemistry of the Earth, 9, p. 1-15.

Hoffman, P.F. 1989. Precambrian geology of tectonic history of North America. In geology of North America-An overview, A.W. Bally and A.R. Palmer, (eds.), Boulder, Colorado. Geological Society of America, A:447-512

Mitchell, R.H., 1986. Kimberlites: Mineralogy, geochemistry and petrology. Plenum Publishing, New York. 442pp. 